\title{
Short communication: Feeding fat from distillers dried grains with solubles to dairy heifers: III. Effects on posttrial reproductive and lactation performance
}

\author{
J. L. Anderson, ${ }^{1}$ K. F. Kalscheur, ${ }^{2}$ A. D. Garcia, and D. J. Schingoethe \\ Dairy Science Department, South Dakota State University, Brookings 57007
}

\begin{abstract}
The objective of this research was to determine the subsequent effects on lactation and reproductive performance from feeding fat from distillers dried grains with solubles (DDGS) to growing dairy heifers. During the prepubertal growth phase, 33 Holstein heifers $(133 \pm 18 \mathrm{~d}$ old $)$ were used in a 24 -wk randomized complete block design. Treatments included (1) a control diet $(\mathrm{CON})$ containing ground corn and soybean products, 2) a diet with low-fat DDGS (LFDG), and (3) a higher-fat diet with traditional DDGS (HFDG). All diets contained $39.8 \%$ grass hay, $24.8 \%$ corn silage, and $1.5 \%$ vitamins and minerals. Previous results demonstrated that growth performance was maintained across treatments, but plasma cholesterol and fatty acids were greater and puberty may occur earlier in heifers fed HFDG. It was hypothesized that differences among treatments in metabolic profile and puberty may influence reproductive and first-lactation performance. Posttrial data on reproductive performance and milk production for the first 4 mo of lactation were collected for each heifer from dairy herd records. At 3 wk prepartum and at calving, body weights, body condition scores, and body measurements were taken. No differences were observed among treatments for age at conception or age at calving. At calving, heifers fed the HFDG were shorter in withers height compared with heifers fed the other diets. Milk yields and components were similar or improved in heifers fed the distillers grains diets compared with heifers fed CON. Heifers fed LFDG had greater milk production and a tendency for greater milk protein yields compared with the heifers fed CON. Energy-corrected milk yields were similar among treatments. Feeding increased dietary fat from DDGS during the prepubertal growth phase did not
\end{abstract}

\footnotetext{
Received November 26, 2014.

Accepted April 25, 2015.

${ }^{1}$ Corresponding author: jill.anderson@sdstate.edu

${ }^{2}$ Current address: US Dairy Forage Research Center, USDA-ARS, 1925 Linden Drive West, Madison, WI 53706.
}

negatively affect milk production, despite earlier attainment of puberty compared with other treatments. The overall ADG for all 3 treatments was $0.96 \mathrm{~kg} / \mathrm{d}$ during the prepubertal period, which is greater than recommended and may have compromised milk yield across treatments. Based on these findings, producers can feed either DDGS or LFDG with corn in replacement of soybean products and corn to prepubertal heifers and maintain or enhance subsequent reproductive and lactation performance. Dietary fat from DDGS can replace starch from corn as an energy source for prepubertal heifers without detriment to later performance. Key words: dairy heifer, distillers grains, first-lactation milk production

\section{Short Communication}

The majority of research on feeding distillers grains to dairy cattle has been with mature cows, as highlighted in a review by Schingoethe et al. (2009). Limited specific research has been done, to date, regarding the effects of feeding distillers grains during the prepubertal growth period on long-term reproductive and lactation performance of dairy heifers. Previous research about feeding distillers grains in beef cattle demonstrated improvements in reproductive performance (Martin et al., 2007; Engel et al., 2008). However, no measures are specific to the effects of feeding distillers grains to dairy heifers during the prepubertal growth phase on subsequent lactation performance.

In our companion papers (Anderson et al., 2015a,b), we demonstrated that dairy heifers fed high dietary inclusion rates of distillers grains maintained growth performance and total-tract digestion of nutrients. However, ADG was high during the feeding trial and averaged $0.96 \mathrm{~kg} / \mathrm{d}$ overall for the 3 treatments. Anderson et al. (2015b) also demonstrated that energy status was maintained among treatments based on similar plasma concentrations of leptin, IGF-1, and insulin. However, feeding increased dietary fat from distillers dried grains with solubles (DDGS) led to increased plasma cholesterol and FA concentrations compared with the lower-fat diets. Increases in these blood lipids 
could positively influence reproductive performance (Talavera et al., 1985; Thomas et al., 1997; Funston, 2004).

How heifers are fed during the rearing period can affect subsequent performance within the herd (Sejrsen and Purup, 1997; Zanton and Heinrichs, 2005). Limited research exists on examining how the form of dietary energy, fed at similar dietary energy concentrations, affects subsequent milk yields. Previous results (Anderson et al., 2015b) indicated that increased dietary fat may decrease the age and BW at puberty. These findings left questions on how the timing of puberty affects mammary gland development and milk yield when ADG was similar among treatments. McFadden et al. (1990) demonstrated in sheep that increased dietary PUFA could enhance mammary parenchymal development. However, Thibault et al. (2003) found no improvement in parenchymal development or milk production when young heifers were fed increased dietary fat from soybean oil during a longer but younger period of growth. These conflicting results raise questions on how differences among species, as well as how the form and composition of supplemented fat, affect physiological development. It is yet to be determined if the negative effects on mammary development caused by an earlier age at puberty can be offset by stimulation of mammary development by increased dietary PUFA. Slaughtering heifers to analyze parenchymal tissue content in the mammary gland, as done by other researchers (Tucker, 1981; Tucker, 2000; Meyer et al., 2006), was beyond the scope of this research. However, heifers were observed for the first 4 mo of lactation to draw some conclusions on mammary development from lactation performance.

The main objective of our research was to determine if feeding fat from distillers grains to dairy heifers during the prepubertal growth phase had lasting effects on later performance. It was hypothesized that, based on beef research, heifers fed increased dietary fat from distillers grains would have improved reproductive performance. Results from earlier research indicated that feeding increased dietary fat from DDGS may decrease age at puberty. Therefore, it was also hypothesized that milk production would decrease compared with heifers fed other low-fat treatments.

All animal use was approved by the South Dakota State University Institutional Animal Care and Use Committee. Heifers were originally fed for $24 \mathrm{wk}$ in a trial described in detail by Anderson et al. (2015a,b). Briefly, the trial was a randomized complete block design with 3 treatments. The 3 treatment diets were (Table 1) a corn-soybean control diet (CON), a diet utilizing a fat extracted, high-protein dried distillers grain that was similar to the control in starch concentration and low in fat (LFDG), and a low-starch diet containing traditional DDGS that was higher in fat (HFDG). Diets were formulated to be isonitrogenous and isocaloric, but not isolipidic. Heifers were on trial from approximately $133 \pm 18$ until $301 \pm 18$ d old. After the experiment feeding period, data were collected on heifer performance as subsequently described.

After completion of the experimental feeding period, heifers were returned to the general herd at the South Dakota State University Dairy Research and Training Facility. A couple heifers from each treatment did not successfully transition through 120 DIM for a variety of reasons unrelated to experimental treatments and had to be removed from data set. Within the herd, heifers were managed under standard farm operating procedures. They were fed common diets according to maturity (bred heifer, transition cow, fresh cow, and lactating cow). Bred heifer diet compositions were approximately $80 \%$ (DM basis) forages and $20 \%$ concentrates, with $14 \% \mathrm{CP}, 46 \% \mathrm{NDF}, 27 \% \mathrm{NFC}$, and $3 \%$ fat. Transition cow diet compositions were approximately $73 \%$ forages and $27 \%$ concentrates, with $14 \%$ CP, $46 \%$ NDF, $27 \%$ NFC, and 3\% fat. Fresh cow diet compositions were approximately $50 \%$ forages and $50 \%$ concentrates, with $17.5 \% \mathrm{CP}, 29 \% \mathrm{NDF}, 40 \%$ NFC, and $5.6 \%$ fat. Finally, lactating cow diet compositions were approximately 50 to $55 \%$ forage and 45 to $50 \%$ concentrates, with $17 \% \mathrm{CP}, 30 \% \mathrm{NDF}, 40 \% \mathrm{NFC}$, and $5.2 \%$ fat. All these diets fluctuated over time, as ingredient availability differed over time; however, as blocks of heifers transition through the herd simultaneously, fluctuations in herd diets should be accounted for by the experimental design.

Data on reproductive performance, which included the number of AI services, date of each AI service, and pregnancy confirmations were collected from herd health records. Age of conception was determined based on when pregnancy was confirmed. On $1 \mathrm{~d}$ at $3 \mathrm{wk}$ prepartum (based on predicted calving date), heifers were weighed approximately $2 \mathrm{~h}$ postfeeding. Body measurements, including withers height, hip height, heart girth, and body length, were also measured. Body length was measured from the top point of the withers to the end of the ischium (Hoffman, 1997). Body condition score was observed by 2 individuals on a quarter-point scale, with 1 being emaciated and 5 being obese (Wildman et al., 1982). Within $48 \mathrm{~h}$ postcalving, heifers were reweighed and measured as previously described. Calf weights were also recorded. Calving took place over a 17-mo period from November 2010 until April 2012, because of the staggered dates that heifers were brought on to the prepubertal feeding trial (start dates based on 
Table 1. Ingredients and composition of the control diet (CON), the low-fat diet containing fat extracted distillers dried grains with solubles (LFDG), and the high-fat diet containing traditional distillers dried grains with solubles (HFDG) fed during the prepubertal growth phase

\begin{tabular}{lccc}
\hline & \multicolumn{3}{c}{ Diet } \\
\cline { 2 - 4 } Item $^{1}$ & CON & LFDG & HFDG \\
\hline Ingredient, \% of DM $_{\text {Grass hay }}$ & 39.79 & 39.78 & 39.79 \\
Corn silage & 24.86 & 24.86 & 24.85 \\
Distillers dried grains with solubles (DDGS) & 0 & 0 & 33.80 \\
Low-fat DDGS & 0 & 21.88 & 0 \\
Corn grain, ground & 15.91 & 11.93 & 0 \\
Soybean meal, 44\% CP & 8.95 & 0 & 0 \\
Expeller soybean meal ${ }^{2}$ & 8.95 & 0 & 0 \\
Limestone & 0.40 & 0.40 & 0.40 \\
Mineral premix & 0.78 & 0.78 & 0.80 \\
Salt & & & \\
Nutrient, \% of DM (unless otherwise indicated) & 0.36 & 0.36 & 0.36 \\
DM, \% of diet & & & \\
CP & 71.0 & 71.8 & 70.7 \\
Ether extract (diethyl) & 15.8 & 16.3 & 16.7 \\
Starch & 2.91 & 3.08 & 7.00 \\
ME, Mcal/kg & 20.4 & 19.0 & 8.3 \\
NE ${ }_{\text {G }}$, Mcal/kg & 2.48 & 2.45 & 2.46 \\
\hline
\end{tabular}

${ }^{1}$ Diets were formulated to meet or exceed requirements with NRC (2001). Nutrient composition based on analysis described by Anderson et al. (2015a).

${ }^{2}$ SoyPlus, West Central Cooperative, Ralston, IA.

${ }^{3}$ Contained $2.2 \mathrm{~g} / \mathrm{kg}$ of lasalocid sodium, $16.05 \% \mathrm{Ca}, 10.0 \% \mathrm{P}, 20.45 \% \mathrm{NaCl}, 2.0 \% \mathrm{Mg}, 0.7 \% \mathrm{~K}, 0.8 \% \mathrm{~S}, 5,520$ $\mathrm{mg} / \mathrm{kg}$ of Zn, 3,700 mg/ $\mathrm{kg}$ of Mn, $1,000 \mathrm{mg} / \mathrm{kg}$ of Fe, $1,010 \mathrm{mg} / \mathrm{kg}$ of $\mathrm{Cu}, 86 \mathrm{mg} / \mathrm{kg}$ of I, $25 \mathrm{mg} / \mathrm{kg}$ of Co, 53 $\mathrm{mg} / \mathrm{kg}$ of Se, $704,000 \mathrm{IU} / \mathrm{kg}$ of vitamin A, 140,800 IU $/ \mathrm{kg}$ of vitamin $\mathrm{D}_{3}$, and $5,280 \mathrm{IU} / \mathrm{kg}$ of vitamin $\mathrm{E}$.

${ }^{4}$ Heifers were provided ad libitum access to white salt $(\mathrm{NaCl})$ blocks, which are not accounted for in these values.

heifer age) and the different amounts of time it required for conception.

Milk data for each heifer were collected (from November 2010 through July 2012) for the first 120 d of lactation from DHIA records. The DIM of sampling were not equal for each heifer because milk samples were collected for analysis by a DHIA representative on random days during each month from the whole lactating herd. Also, calving dates differed for each heifer, making it impossible to have consistent sampling intervals. Therefore, for statistical analysis purposes, data were averaged by month of lactation. These factors, combined with the long period of data collection and small heifer numbers, may have compromised our ability to detect treatment effects; but because of a lack of any data of this nature related to feeding heifers distillers grains, we still felt there was value in reporting these data. Milk samples were analyzed for concentration of fat and protein, and for SCC at Heart of America DHIA laboratory (Manhattan, KS). Mid-infrared spectroscopy (Bentley 2000 Infrared Milk Analyzer, Bentley Instruments, Chaska, MN; AOAC International, 2002) was used for analysis of fat and protein content. A flow cytometer laser (Somacount 500, Bentley Instruments; AOAC International, 2002) was used for SCC. Energy- corrected milk was calculated as: $\mathrm{ECM}=[(0.327 \times \mathrm{kg}$ of milk $)+(12.95 \times \mathrm{kg}$ of fat $)+(7.2 \times \mathrm{kg}$ of protein $)]$ (Orth, 1992).

The MIXED procedures in SAS (Littell et al., 2008) were used for the reproductive and body measurements. The model included treatment, with block included as a random variable. Body measurements taken 3 wk prepartum were analyzed separately from body measurements taken at calving. Least squares means for each treatment are reported in the tables and were separated using Tukey's test. Significance was declared at $P<0.05$. Tendency was declared at $0.05<P \leq 0.10$.

For the milk production data, the MIXED procedures in SAS were also used. Milk production was analyzed using repeated measures by month of lactation. The model included treatment, month, and treatment by month interactions. Best fit covariance structure was assessed based on Akaike's criterion. Significance was declared at $P<0.05$. Tendency was declared at $0.05<$ $P \leq 0.10$.

Feeding increased dietary fat from distillers grains during the prepubertal growth period did not affect reproductive performance compared with heifers fed the CON diet (Table 2). Age at first service was similar among all treatments, because standard operating 
Table 2. Reproductive performance and body measures for heifers fed the control diet (CON), the low-fat diet containing fat extracted distillers dried grains with solubles (LFDG), and the high-fat diet containing traditional distillers dried grains with solubles (HFDG) during the prepubertal growth phase

\begin{tabular}{|c|c|c|c|c|c|}
\hline Item & \multicolumn{3}{|c|}{ Treatment } & SEM & $\begin{array}{c}P \text {-value } \\
\text { Treatment }\end{array}$ \\
\hline Age first service, $\mathrm{d}$ & 394 & 400 & 398 & 5.8 & 0.49 \\
\hline Age at conception, d & 455 & 483 & 444 & 16.98 & 0.27 \\
\hline Actual age first calving, $d$ & 733 & 764 & 728 & 17.40 & 0.30 \\
\hline \multicolumn{6}{|l|}{ Body measure, 3 wk prepartum } \\
\hline Hip height, cm & 147.1 & 146.5 & 143.7 & 2.07 & 0.15 \\
\hline Heart girth, cm & 206.2 & 205.9 & 203.0 & 2.22 & 0.51 \\
\hline Body length, cm & $145.0^{\mathrm{a}}$ & $143.7^{\mathrm{a}}$ & $140.1^{\mathrm{b}}$ & 1.36 & 0.04 \\
\hline BCS & 3.41 & 3.41 & 3.39 & 0.07 & 0.98 \\
\hline \multicolumn{6}{|l|}{ Body measure, at parturition } \\
\hline $\mathrm{BW}, \mathrm{kg}$ & 634.3 & 620.6 & 590.3 & 31.46 & 0.20 \\
\hline Withers height, $\mathrm{cm}$ & $145.8^{\mathrm{a}}$ & $147.6^{\mathrm{a}}$ & $143.1^{\mathrm{b}}$ & 1.13 & 0.03 \\
\hline Calving problems, ${ }^{1}$ no. & 1 & 2 & 2 & - & - \\
\hline Successfully transitioned, ${ }^{2}$ no. & 9 & 9 & 9 & - & - \\
\hline
\end{tabular}

procedure at the South Dakota State University Dairy Research and Training Facility is to start breeding all heifers in the herd at approximately 13.5 mo of age. Heifers fed HFDG required numerically fewer $(P=$ 0.11) AI services for conception compared with heifers fed the LFDG diet (1.78 vs. 2.89, respectively). Heifers that were fed CON were in between the distillers grains treatments, requiring 2.11 AI services for conception.

At 3 wk prepartum and at parturition, heifers that were fed the HFDG diet had shorter withers heights and body lengths compared with CON and LFDG fed heifers. The heifers fed the HFDG prepubertal diet weighed numerically less at $3 \mathrm{wk}$ prepartum and at calving, although small numbers and high standard error of the mean prevented finding a statistical difference. Calf weights were similar among treatments. No increase in health problems were observed among treatments, as noted by similar number of calving problems (Table 2).

Milk production (Table 3) was similar or even enhanced in the heifers fed the distillers grains diets compared with CON during the prepubertal growth phase. The heifers fed LFDG had increased milk production compared with heifers fed CON, whereas the heifers fed HFDG had intermediate production (similar to both). A $1.7-\mathrm{kg} / \mathrm{d}$ milk production increase was observed in the HFDG compared with CON, as well as a $1.7-\mathrm{kg} / \mathrm{d}$ milk production difference between LFDG and HFDG, but the small number of heifers with data collection over long period of time limited the sensitivity and ability to detect as statistical difference. When components were factored in, ECM was similar among heifers fed all treatment diets. Milk protein yield also tended to be greater from heifers fed LFDG compared with CON. Milk fat concentrations, milk fat yields, and SCC were similar among treatments.

It has been recommended that Holstein replacement heifers should be between 580 to $635 \mathrm{~kg}$ of BW at calving (Hoffman, 1997). Heifers on this trial were within this range. In general, any difference in body sizes at 3 wk prepartum or at calving can be related to age at conception. Heart girth, hip heights, and BCS were similar among treatments, demonstrating that prepubertal diets had no treatment effect on posttrial growth performance.

Past research in beef heifers showed that heifers in the first estrous cycle are less fertile than heifers in the third estrous cycle (Byerley et al., 1987). Results presented in our companion paper (Anderson et al., 2015b) indicated that heifers fed the HFDG diet may have attained puberty earlier than heifers on the CON and LFDG diets. This means that heifers fed the HFDG diet would, potentially, have had the opportunity to go 
Table 3. Milk production performance based on DHIA records for heifers fed the control diet (CON), the lowfat diet containing fat extracted high-protein distillers dried grains (LFDG), and the high-fat diet containing traditional distillers dried grains with solubles (HFDG) during the prepubertal growth phase

\begin{tabular}{lccccc}
\hline & \multicolumn{3}{c}{ Treatment } \\
\cline { 2 - 4 } Item & CON & LFDG & HFDG & SEM & P-values \\
\hline Heifers, no. & 9 & 9 & 9 & - & - \\
Age freshened, d & 732 & 764 & 728 & 17.4 & 0.30 \\
Milk yield, kg/d & $33.0^{\mathrm{b}}$ & $36.4^{\mathrm{a}}$ & $34.7^{\mathrm{ab}}$ & 1.35 & 0.03 \\
ECM, $\mathrm{kg} / \mathrm{d}$ & 34.4 & 37.9 & 35.1 & 1.48 & 0.15 \\
Protein, \% & 2.94 & 3.01 & 3.03 & 0.043 & 0.13 \\
Protein, kg/d & 0.98 & 1.08 & 1.03 & 0.041 & 0.06 \\
Fat, \% & 3.98 & 3.94 & 3.86 & 0.180 & 0.84 \\
Fat, $\mathrm{kg} / \mathrm{d}$ & 1.28 & 1.41 & 1.28 & 0.078 & 0.30 \\
Somatic cells, $\times 10^{3} / \mathrm{mL}$ & 53.4 & 124.4 & 299.6 & 125.5 & 0.13 \\
\hline
\end{tabular}

${ }^{\mathrm{a}, \mathrm{b}}$ Values within a row with unlike superscripts differ $(P<0.05)$.

${ }^{1} \mathrm{ECM}=[(0.327 \times \mathrm{kg}$ of milk $)+(12.95 \times \mathrm{kg}$ of fat $)+(7.2 \times \mathrm{kg}$ of protein $)]($ Orth, 1992).

through more estrous cycles before breeding age, which may explain why those heifers numerically require fewer AI services to conceive, especially compared with heifers fed the LFDG diet.

Heifers fed either of the distillers grains diets had similar or increased milk production compared with the heifers fed CON, which means distillers grains can be chosen over corn and soybeans depending on economics. Heifers fed LFDG had greater milk production compared with heifers fed CON. Because onset of puberty appeared to be later for this diet, these heifers may have had better parenchyma development (Sejrsen and Purup, 1997; Sejrsen et al., 2000). Better mammary gland development is thought to result in increased milk yields. Conversely, these heifers took longer (numerically) to get bred and enter the lactating herd (approximately 1 mo longer) compared with heifers fed the other treatments. Therefore, the benefit of increased milk production has to be considered against the extra time, labor, and resources to get a return on investment. (Tozer and Heinrichs, 2001). It was a concern that earlier puberty would result in decreased milk production, but it could be possible that benefits of the increase dietary fat (such as increased PUFA) offset some of the negative effects. These findings warrant more research with larger numbers of heifers, especially on the interactions of dietary fat, puberty, and mammary development.

It should be noted that during the prepubertal growth period heifers had ADG of 0.95, 0.96, and 0.98 $\mathrm{kg} / \mathrm{d}$ for CON, LFDG, and HFDG, respectively. These ADG also indicate that heifers were on a high plane of nutrition throughout the 6-mo prepubertal feeding period. These rates of gain are above the recommended $0.8 \mathrm{~kg} / \mathrm{d}$ (Zanton and Heinrichs, 2005) and could potentially have cost some milk yield for all 3 treatments. Because all 3 treatments were high for ADG and were not statistically different, comparison of the different nutrients, starch versus fat, are still valid.

Results from this research demonstrate that feeding increased dietary fat from DDGS in replacement of starch from corn during the prepubertal growth period does not compromise later performance. Reproductive performance was maintained by feeding increased dietary fat from DDGS in replacement of starch from corn during the prepubertal period. Milk production was similar for the heifers fed HFDG containing traditional DDGS compared with heifers fed the CON diet containing corn and soybean products. Heifers fed the LFDG diet containing low-fat DDGS had increased milk yields compared with heifers fed the CON diet. Based on these findings, feeding prepubertal heifers either traditional DDGS or low-fat DDGS with corn are viable alternatives to feeding corn and soybean products for dairy producers. When feeding prepubertal heifers, dietary fat from DDGS can be used as an energy source in replacement of starch from corn without detriment to subsequent performance.

\section{ACKNOWLEDGMENTS}

This work was supported in part by the South Dakota Agriculture Experiment Station (Brookings) and USDA-Agricultural Research Service (Washington, DC) Agreement No. 58-5447-7-322, and was a component of NC-1042: Management Systems to Improve the Economic and Environmental Sustainability of Dairy Enterprises. In memoriam, the authors gratefully acknowledge the role that Arnold Hippen had in helping to plan this research.

\section{REFERENCES}

Anderson, J. L., K. F. Kalscheur, J. A. Clapper, G. A. Perry, D. H. Keisler, A. D. Garcia, and D. J. Schingoethe. 2015a. Feeding 
fat from distillers dried grains with solubles to dairy heifers: II. Effects of metabolic profile. J. Dairy Sci. 98:5709-5919. http:// dx.doi.org/10.3168/jds.2014-9163.

Anderson, J. L., K. F. Kalscheur, A. D. Garcia, and D. J. Schingoethe. 2015b. Feeding fat from distillers dried grains with solubles to dairy heifers: I. Effects on growth performance and total tract digestibility of nutrients. J. Dairy Sci. 98:5699-5708. http://dx.doi. org/10.3168/jds.2014-9162.

AOAC International. 2002. Official Methods of Analysis. 17th ed. AOAC International, Gaithersburg, MD.

Byerley, D. J., R. B. Staigmiller, J. G. Berardinelli, and R. E. Short. 1987. Pregnancy rates of beef heifers bred either on pubertal or third estrus. J. Anim. Sci. 65:645-650.

Engel, C. L., H. H. Patterson, and G. A. Perry. 2008. Effect of dried corn distillers grains plus soluble compared with soybean hulls, in late gestation heifer diets, on animal and reproductive performance. J. Anim. Sci. 86:1697-1708.

Funston, R. N. 2004. Fat supplementation and reproduction in beef females. J. Anim. Sci. 82(E. Suppl.):E154-E161.

Hoffman, P. C. 1997. Optimum body size of Holstein replacement heifers. J. Anim. Sci. 75:836-845.

Littell, R. C., G. A. Milliken, W. W. Stroup, R. D. Wolfinger, and O. Schabenberger. 2008. SAS for Mixed Models, 2nd ed. SAS Institute, Cary, NC.

Martin, J. L., A. S. Cupp, R. J. Rasby, Z. C. Hall, and R. N. Funston. 2007. Utilization of dried distillers grains for developing beef heifers. J. Anim. Sci. 85:2298-2303.

McFadden, T. B., T. E. Daniel, and R. M. Akers. 1990. Effects of plane of nutrition, growth hormone, and unsaturated fat on mammary growth in prepubertal lambs. J. Anim. Sci. 68:3171-3179.

Meyer, M. J., A. V. Capuco, D. A. Ross, L. M. Lintault, and M. E. Van Amburgh. 2006. Development and nutritional regulation of the prepubertal heifer mammary gland: I. Parenchyma and fat pad mass and composition. J. Dairy Sci. 89:4289-4297.

NRC. 2001. Nutrient Requirements of Dairy Cattle. 7th rev. ed. Natl. Acad. Press, Washington, DC

Orth, R. 1992. Sample Day and Lactation Report. DHIA 200 Fact Sheet A-2. Mid-states DRPC, Ames, IA
Schingoethe, D. J., K. F. Kalscheur, A. R. Hippen, and A. D. Garcia. 2009. Invited review: The use of distillers products in dairy cattle diets. J. Dairy Sci. 92:5802-5813.

Sejrsen, K., and S. Purup. 1997. Influence of prepubertal feeding level on milk yield potential of dairy heifers: A review. J. Anim. Sci. 75:828-835.

Sejrsen, K., S. Purup, M. Vestergaard, and J. Foldager. 2000. High body weight gain and reduced bovine mammary growth: Physiological basis and implications for milk yield potential. Domest. Anim. Endocrinol. 19:93-104.

Talavera, F. C. S. Park, and G. L. Williams. 1985. Relationships among dietary lipid intake, serum cholesterol and ovarian function in Holstein heifers. J. Anim. Sci. 60:1045-1051.

Thibault, C., D. Petitclerc, R. Spratt, M. Leonard, K. Sejrsen, and P. Lacasse. 2003. Effect of feeding prepubertal heifers with a high oil diet on mammary development and milk production. J. Dairy Sci. 86:2320-2326.

Thomas, M. G., B. Bao, and G. L. Williams. 1997. Dietary fats varying in their fatty acid composition differentially influence follicular growth in cows fed isoenergetic diets. J. Anim. Sci. 75:2512-2519.

Tozer, P. R., and A. J. Heinrichs. 2001. What affects the costs of raising replacement dairy heifers: A multiple-component analysis. J. Dairy Sci. 84:1836-1844.

Tucker, H. A. 1981. Physiological control of mammary growth, lactogenesis, and lactation. J. Dairy Sci. 64:1403-1421.

Tucker, H. A. 2000. Symposium: Hormonal regulation of milk synthesis. Hormones, mammary growth, and lactation: A 41-year perspective. J. Dairy Sci. 83:874-884.

Wildman, E. E., G. M. Jones, P. E. Wagner, R. L. Boman, H. F Troutt Jr., and T. N. Lesch. 1982. A dairy cow body condition scoring system and its relationship to standard production characteristics. J. Dairy Sci. 65:495-501.

Zanton, G. I., and A. J. Heinrichs. 2005. Meta-analysis to assess effect of prepubertal average daily gain of Holstein heifers on firstlactation production. J. Dairy Sci. 88:3860-3867. 